\title{
8. LOWER CRETACEOUS OOLITES FROM THE MID-PACIFIC MOUNTAINS (RESOLUTION GUYOT, SITE 866) ${ }^{1}$
}

\author{
Hugh C. Jenkyns ${ }^{2}$ and André Strasser ${ }^{3}$
}

\begin{abstract}
On Resolution Guyot, in the Mid-Pacific Mountains, two major intercalations of oolitic limestone have developed, one of latest Hauterivian-Barremian age, which rests directly on edifice basalt, and the second of Aptian age, which is sandwiched between lagoonal-peritidal carbonate sediments. Both oolite packages may be interpreted as the sedimentary response to an increase in the generation of accommodation space; in the first instance, probably related to high rates of basement subsidence, in the second, to a probable eustatic rise in sea level. The ooids vary in structure from micritic and featureless through micritic and concentrically laminated to radial and commonly show combinations of these fabrics. Radial cortical structures, however, predominate. Although oolitic sediment is extraordinarily rare in the Pacific Ocean today, other records show that it was a widespread facies capping many volcanic edifices during the Cretaceous.
\end{abstract}

\section{INTRODUCTION}

One of the notable features of the 1.6-km-thick section of shallowwater carbonates cored on the northern rim of Resolution Guyot during Leg 143 (Site 866, Mid-Pacific Mountains: Fig. 1) is the presence of two major packages of Cretaceous oolitic limestone, the stratigraphically lower of which is partially dolomitized. Such a discovery was not entirely unexpected given that redeposited oolites of Barremian-Aptian age were recorded from Site 463 in a basinal section situated some $44 \mathrm{~km}$ to the east of the guyot (Thiede, Vallier, et al., 1981; Ferry and Schaaf, 1981). Elsewhere on Resolution Guyot (Site 867: Fig.1), a thin intercalation of oolitic limestone lying 30 to $45 \mathrm{~m}$ below the top of the shallow-water carbonates was recovered.

Earlier drilling records of oolitic facies from the Pacific Ocean include that described by Hesse (1973) from atop Ita Matai Guyot (Site 202) at the eastern margin of the Mariana Basin, where the dating is inexact but known to be pre-Eocene, and the redeposited Aptian-Albian ooids from Site 585 in an adjacent deep-water area to the north (Haggerty and Premoli Silva, 1986). Ooids that resemble some of these latter occur in Cenomanian-Campanian redeposited volcaniclastic sediments cored on the flanks of Wodejebato (formerly Sylvania) Guyot (Site 869) during Leg 143 (Sager, Winterer, Firth, et al., 1993). Furthermore, during Leg 144, Cretaceous (lower Aptian) oolitic sediments were recovered from "MIT" Guyot, an isolated feature close to the Wake Group (Premoli Silva, Haggerty, Rack, et al., 1993).

Cretaceous shallow-water facies have been dredged from Ita Matai Guyot (Haggerty and Premoli Silva, 1986), and the cored oolitic material is almost certainly of this age. Other dredge-hauls have recovered Cretaceous oolite from a number of Pacific locations. Allison Guyot has yielded some oolitic material as has "Vibelius" Guyot in the Wake Seamount Group (Grötsch and Flügel, 1992) and, moving farther west, two seamounts from the Magellan Group and another unnamed topographic feature lying close to the Mariana Trench (Haggerty and Premoli Silva, 1986). These scattered records indicate that, unlike the situation today, oolites were a common feature of Cretaceous shallowwater environments on the ancestral Pacific Plate (Fig. 2). Cretaceous oolitic limestones present in the allochthonous Franciscan Complex in

\footnotetext{
'Winterer, E.L., Sager, W.W., Firth, J.V., and Sinton, J.M. (Eds.), 1995, Proc. ODP, Sci. Results, 143: College Station, TX (Ocean Drilling Program).

${ }^{2}$ Department of Earth Sciences, University of Oxford, Parks Road, Oxford, OXI 3PR, United Kingdom.

${ }^{3}$ Institut de Géologie, Université de Fribourg, Pérolles, 1700 Fribourg, Switzerland.
}

California indicate that shallow-water plateaus on the vanished Farallon Plate were also characterized by similar environments (Bailey et al., 1964; Wachs and Hein, 1974; Tarduno et al., 1985).

Formation of oolitic facies in the Pacific Basin persisted during the Paleocene and Eocene and locally continued into the Holocene on at least one atoll (Schlanger, 1987).

\section{STRATIGRAPHIC AGE OF OOLITIC LIMESTONES}

Two distinct sequences of oolitic facies are present in the section cored on Resolution Guyot (Site 866), the stratigraphically lower of which rests directly on basalt (Fig. 3). Biostratigraphic data from rare planktonic and more abundant benthic foraminifers, together with strontium- and carbon-isotope stratigraphy, suggest that the basal oolitic package can be assigned to the latest Hauterivian-Barremian (Arnaud-Vanneau and Sliter, this volume; Jenkyns, this volume; Jenkyns et al., this volume). A cluster of absolute ages close to $127 \mathrm{Ma}$, determined for the underlying basalt (Pringle and Duncan, this volume), is consistent with this age assignment, as such a value would fall at the Hauterivian/Barremian boundary in the time scale of Obradovich (1993). However, this particular part of the Cretaceous time scale is poorly constrained owing to the paucity of reliable dates (c.f., Harland et al., 1982, 1990, who place an age of $127 \mathrm{Ma}$ in the Hauterivian and Barremian, respectively).

The higher oolitic package can be dated with some certainty as the carbon-isotope curve generated for Resolution Guyot carbonates is particularly diagnostic in this part of the section (Jenkyns, this volume). It is of Aptian age and, using the planktonic foraminiferal biostratigraphic scheme, in all probability extends from the summit of the blowi Zone through the cabri,ferreolensis, and algerianus zones.

The thin development of oolitic facies cored in Hole 867B is dated as late Albian (Winterer, Sager, Firth, et al., 1993).

\section{FACIES OF OOLITIC LIMESTONES}

\section{Hauterivian-Barremian Oolitic Package}

The oldest oolitic facies that can be recognized as a distinct stratigraphic division rest directly on basalt and are constituted by gray pyritic oolitic grainstones to rudstones (Subunit VIIIB: Fig. 4). Apart from ooids, peloids also are present, as are oncoids and aggregate grains of millimeter-scale locally. Intraclasts of oolitic grainstone occur, and tiny green clasts of probable igneous origin also are found. Skeletal remains include gastropods, which may have oncolitic coatings, together with coral, echinoderm, bivalve and bryozoan remains, 


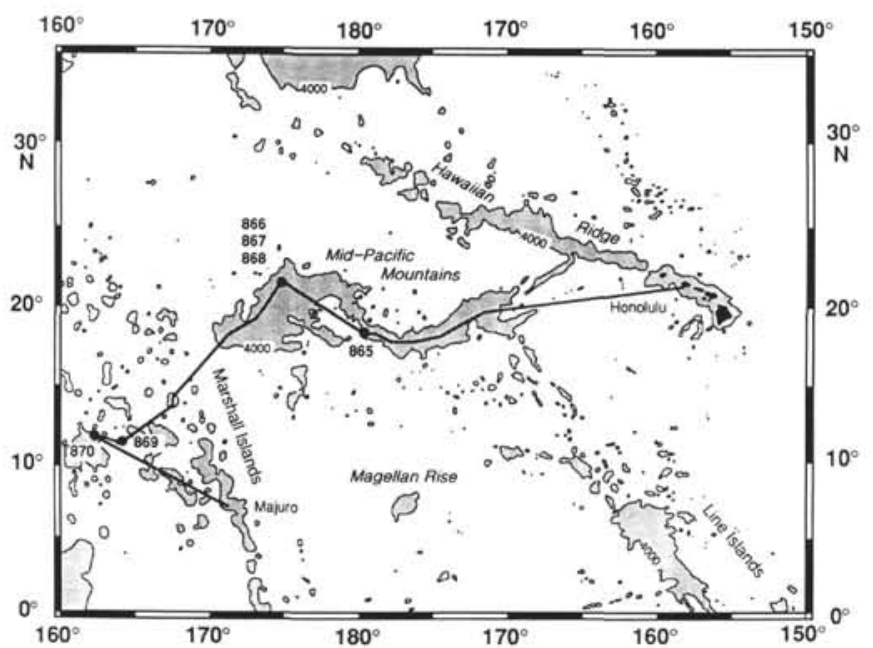

Figure 1. Map of portion of the Pacific Ocean, illustrating location of drill sites cored during Leg 143. Site 866 is the deep site drilled on Resolution Guyot: two intervals of Lower Cretaceous oolitic sediment (Hauterivian-Barremian and Aptian) are present. Hole 867B has yielded limestones with a thin intercalation of Albian oolitic facies. Redeposited ooids of Late Cretaceous age occur at Site 869 .

and foraminifers, as well as green and red algae and microbial lumps, together with Girvanella and Bacinella. The grains exhibit some degree of overpacking, with residual void space of about $10 \%$. Very sparse dolomite rhombs occur, filling some void space and replacing ooids.

The gray pyritic limestones are overlain by the buff-colored oolitic and peloidal grainstones of Subunit VIIIA that locally contain grapestones and intraclasts; these latter display early fringing cements and probably represent reworked pieces of hardground. The sorting is generally good, and cross-lamination is present in parts of the section. Faunal and floral elements are as in the underlying unit. Finer-grained and more muddy lithologies, such as packstone, wackestone, and rarer mudstone, occur at some levels, as do algal laminites. There is minor burrow mottling. A characteristic feature of this part of the section is the presence of centimeter-scale oncoids which locally are hydrodynamically sorted and graded (Fig. 5). Scattered black anastomosing clay seams of millimeter- to centimeter-scale occur, as do stylolites.

Dolomite is pervasive in the lower part of this subunit. It is typically colored various shades of tan through brown, more rarely black, and is sucrosic and vuggy. Pyrite crystals are locally present. Dolomitization may be total, with the oncoids recognizable as vague spherical ghosts, but becomes less significant upsection as oncoids, ooids, and other particles begin to appear as unreplaced calcitic relics (Fig. 6 ) and is ultimately manifested in a patchy and irregular manner. In the latter case, the dolomite is interstitial and is present as a coarsergrained intergranular fill. In some cores, fringe cements are visible as relics (Fig. 7). Considerable void space $(10 \%-20 \%)$ remains, but this is greatly reduced in some facies where overpacking and interpenetration of ooids and peloids is particularly prominent. Where spalling of outer ooid cortices has taken place, some of the ruptured particles are coated with cement rims (Fig. 8). Such compaction phenomena are less significant in those facies cemented by coarse-grained interstitial dolomite or calcite (Fig. 9).

A major facies change is present at the contact with the overlying Unit VII. Finer-grained lithologies (such as packstones, wackestones, and mudstones) assume more importance in this unit, although white to buff to brown oolitic, oncolitic, and peloidal grainstones are present in Subunit VIID. As in the underlying facies, considerable porosity, both primary and secondary, is present locally. Horizontally disposed microbial laminites occur throughout this part of the section, and several of these contain fenestral pores and desiccation cracks. Lo-

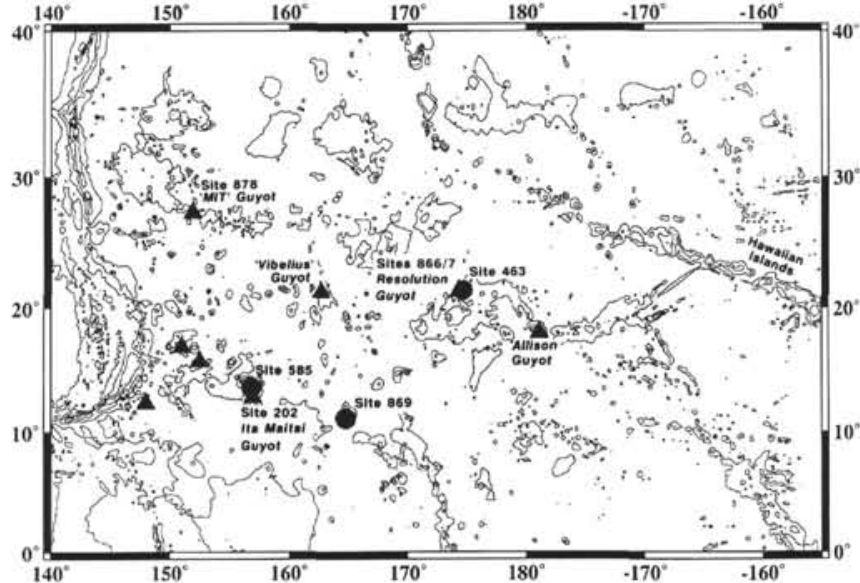

Figure 2. Map of a broad area of the Pacific, showing locations (black triangles and circles) where Cretaceous oolitic limestones have been cored or dredged. Data from sources in text. Bathymetric contours at $2 \mathrm{~km}$. At Sites 463, 585, and 869 , the ooids have been redeposited and occur as intercalations in deep-water facies (filled circles); in the other locations (filled triangles), they occur atop or on the flanks of volcanic pedestals and presumably are more or less in situ. The distribution suggests that oolites were commonly developed on shallow-water topographic highs across the Pacific Plate during the Cretaceous.

cally, the laminites are grouped together to produce centimeter-thick clay/organic-rich layers. The biota are mainly gastropods, bivalves including oysters, corals, echinoids, benthic foraminifers, and green algae. Patchy dolomitization is present throughout. Subunit VIIC comprises porous buff-colored peloidal grainstone, locally oolitic and rich in bivalve and gastropod debris, as well as scattered rudist, echinoid, stromatoporoid, coral, and possible sclerosponge fragments. The overlying Subunit VIIB comprises white sucrosic dolomites that have completely replaced the original grainstones, which may well have contained an oolitic component. Relict sedimentary structures, such as keystone vugs (Dunham, 1970), are recognizable locally. Subunit VIIA consists of pale brown to brown dolomitized wackestones to grainstones that contain bird's-eye and keystone vugs accompanied by traces of bioturbation. Oncoids, ooids, peloids, and blackened intraclasts constitute significant grain types and are accompanied by bivalves, gastropods, benthic foraminifers, and serpulid worm tubes. The basal part of Subunit VIC (Cores 143-866A-124R, $-125 R$, and -126R) contains some ooids and coated grains as constituents of packstones and grainstones. Locally, oolitic grainstones contain meniscus cements (Dunham, 1971; Fig. 10).

The total thickness of facies that contains an oolitic component thus is in excess of $400 \mathrm{~m}$. In general, ooids become a decreasingly important part of the section as it is traced upward.

\section{Aptian Oolitic Package}

Some ooids reappear at the top of Subunit VIC and in Subunit VIB, but they reach their acme of abundance in Unit V, where some $115 \mathrm{~m}$ of dominantly oolitic grainstone have developed. Essentially, the oolitic section occurs sandwiched between finer-grained, more muddy lithologies, such as cyclic packstone-wackestones. The oolitic limestone is buff to beige in color and locally cross-laminated. The ooids are generally well sorted, with different grain-size populations clearly recognizable, some levels showing a bimodal distribution of oolitic particles. Peloids, grapestones, intraclasts and rare oncoids also are present. Bioclastic material includes bivalve debris, echinoderm plates, which locally carry syntaxial overgrowths, corals, gastropods, foraminifers, and dasycladacean algae. Keystone vugs are present at several discrete levels (Strasser et al., this volume). Although grainstones constitute the bulk of the section small intervals 

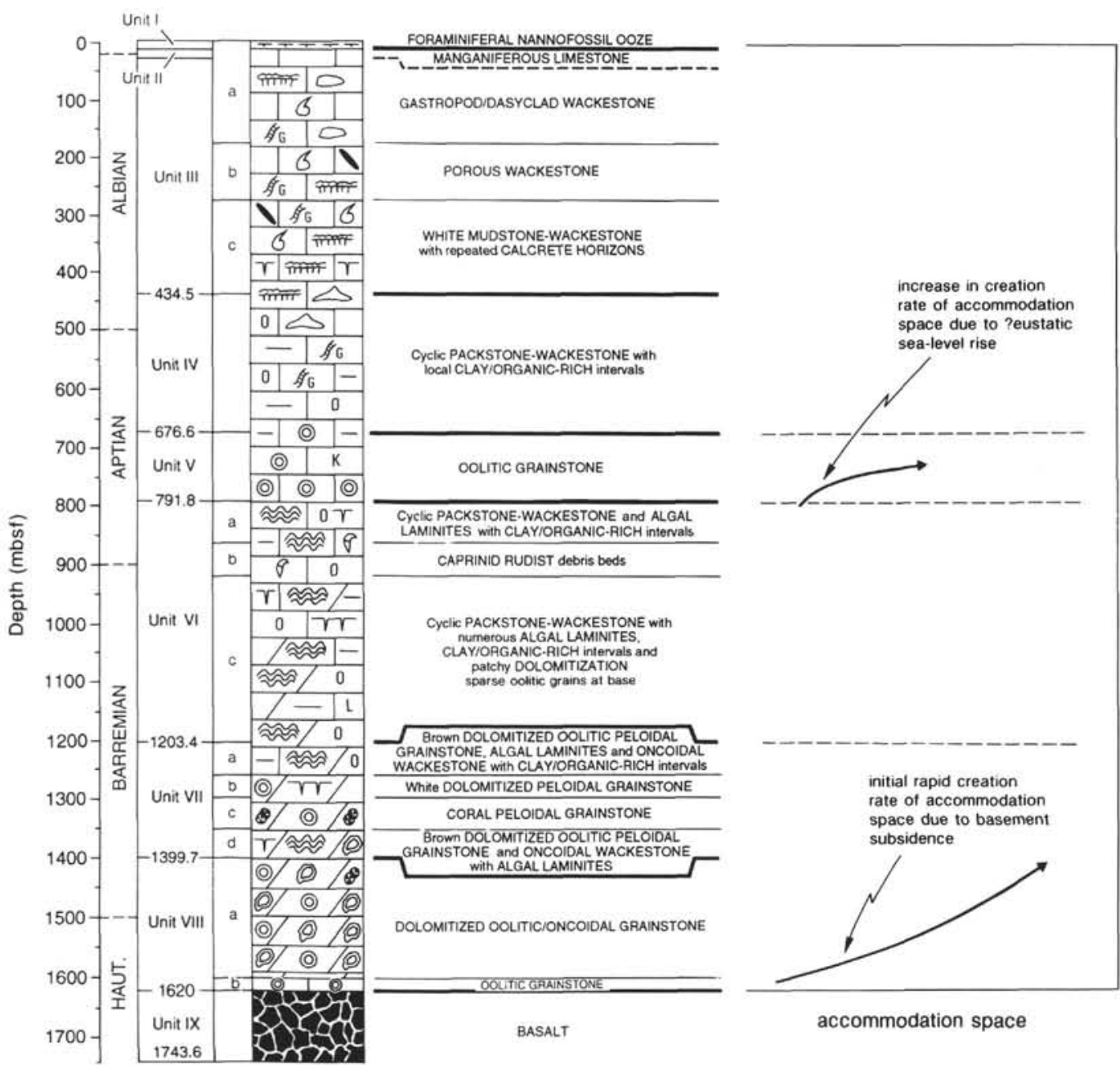

\begin{tabular}{|c|c|}
\hline \multicolumn{2}{|c|}{ Fossils } \\
\hline 0 & Gastropods \\
\hline p & Caprinid rudists \\
\hline 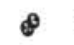 & Corals \\
\hline I & Sponge spicules \\
\hline$s$ & Orbitolinid toraminifers \\
\hline $8_{6}$ & Green algae \\
\hline \multicolumn{2}{|c|}{ Accessories } \\
\hline (?) & Ooids \\
\hline (2) & Oncoids \\
\hline$\approx$ & Algal mat \\
\hline की & Calcrete \\
\hline 0 & Organic matter \\
\hline 0 & Lithoclasts \\
\hline L & Limonitic layers \\
\hline Stru & uctures \\
\hline rr & Desiccation cracks \\
\hline k & Keystone vugs \\
\hline
\end{tabular}

Figure 3. Stratigraphic section of Resolution Guyot, showing the suggested relationship between the development of oolitic facies and changes in accommodation space.

of rudstone and packstone can be seen and, locally, peloids replace ooids as the dominant grain type. Aggregates bound by fibrous cements can be interpreted as reworked pieces of hardground (Fig. 11). One particular level of wackestone even contains charophytes (Arnaud et al., this volume). There is limited burrow mottling.

\section{PETROGRAPHY AND GENESIS OF CRETACEOUS PACIFIC OOLITES FROM RESOLUTION GUYOT}

The petrographic analysis of the ooids is based on examination of 45 thin sections of oolitic sediment. In addition, 18 rock samples, etched (for $3 \mathrm{~s}$ in $5 \% \mathrm{HCl}$ ), rinsed, dried (for $72 \mathrm{hr}$ at $30^{\circ} \mathrm{C}$ ) and gold-coated, have been studied under the stereoscan electron microscope.

No obvious petrographic difference exists between the HauterivianBarremian and Aptian ooids except that, in those facies that directly overlie basalt, tiny igneous clasts locally act as nuclei and pyrite, locally framboidal, may reside in the cores of the grains or on their surface (Fig. 4). Nuclei of the ooids are constituted principally by peloids, more rarely by bivalve or echinoderm fragments, foraminifers, intraclasts, or a piece of replacement spar. Ooid diameter typically varies between 0.2 and 0.6 $\mathrm{mm}$, the extremes being 0.1 and $0.8 \mathrm{~mm}$, respectively. Ooids with multiple nuclei occur rarely.

Under the petrographic microscope, the dominant oolitic structure is seen to be radial, although micritization to varying degrees is common. Micritization may follow concentric layers or define sectors

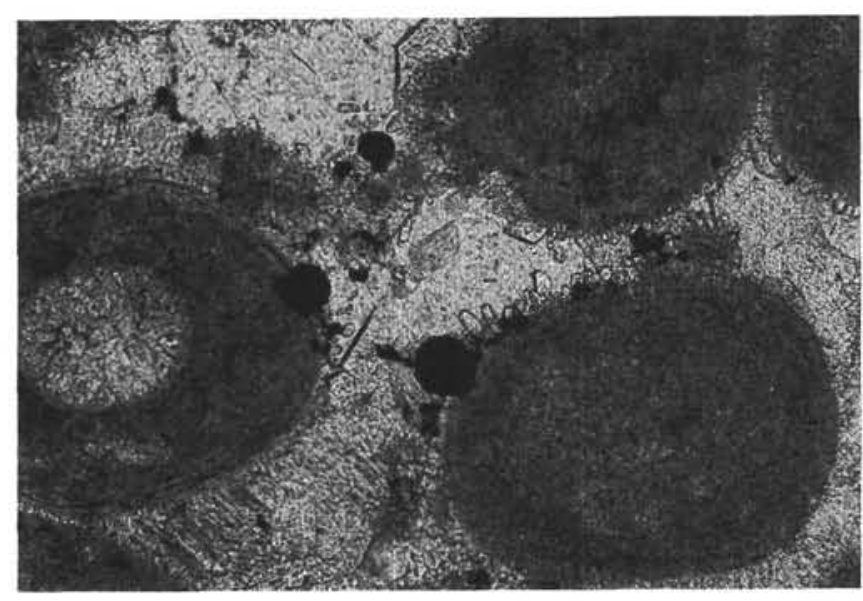

$0 . \overline{\mathrm{mm}}$

Figure 4. Oolitic grainstone, showing early fringing cement and later pore-filling cement. Ooids are micritic and show faint concentric structure. Framboidal pyrite (black spots) is abundant and concentrated on ooid surfaces. It formed before, together with, or shortly after, the fringing cement (Photomicrograph, plane light, Interval 143-866A-171R-1, 38-40 cm; scale $0.1 \mathrm{~mm}$; Subunit VIIIB, Hauterivian). 


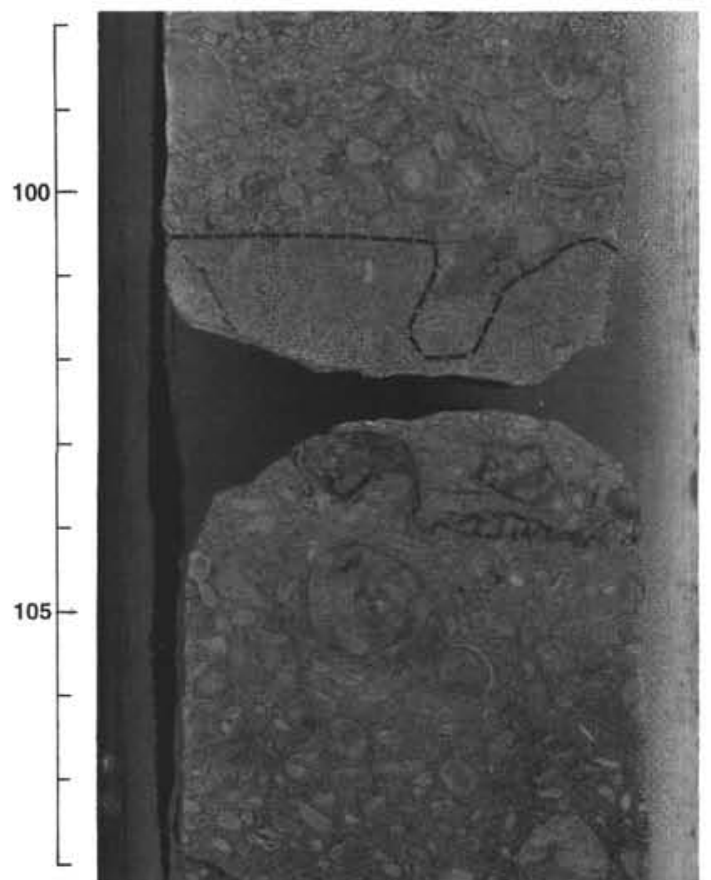

Figure 5. Oolitic-oncolitic grainstone-rudstone with bimodal grain distribution. Note stylolite following former hardground surface and infill of possible bioerosional void (outlined). Reworked pieces of hardground and hydrodynamically sorted grains appear in lower piece of core (Interval 143-866A167R-2, 98-108 cm; Subunit VIIIA, Hauterivian).

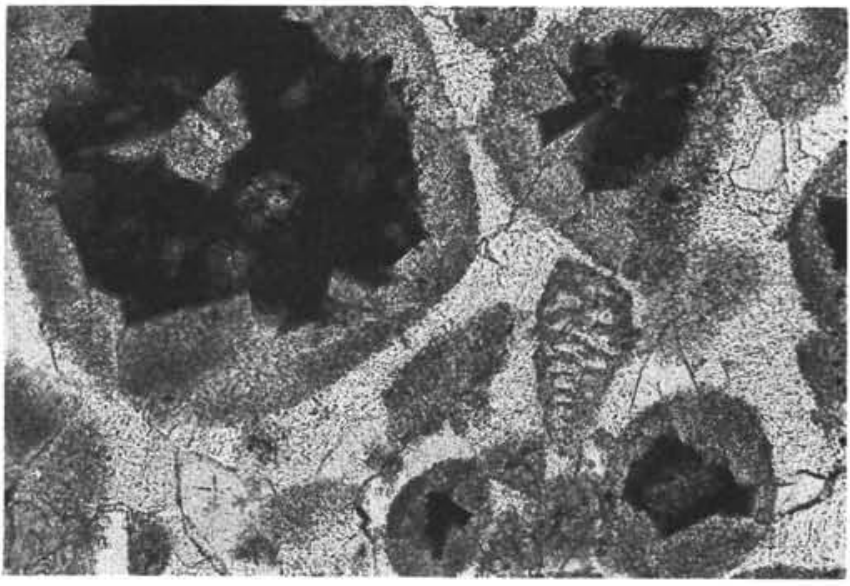

$0 . \overline{\mathrm{mm}}$

Figure 6. Dolomitized oolitic-oncolitic grainstone with calcitic relics of oncoids (dark in photograph) and ghost-structures of smaller particles including a foraminifer (Photomicrograph, plane light, Interval 143-866A-163R-1, 75-78 cm; scale $0.1 \mathrm{~mm}$; Subunit VIIIA, Hauterivian).

of the cortex (Figs. 7,9). Some ooid cortices are completely micritic, with very thin concentric laminations (Fig. 4). Superficial ooids that display only one cortical layer occur locally, but are subordinate.

Under the scanning electron microscope, most ooids reveal a cortex comprising a radial arrangement of crystals that are disposed in concentric layers (Fig. 12). Patches of micrite within the cortex are common. It is not clear whether these formed by the action of a primary bacterially mediated process around the growing cortex or as a result of secondary micritization of originally radial crystals. Spherulites in some ooid cores (Fig. 13) suggest localized bacterial activity

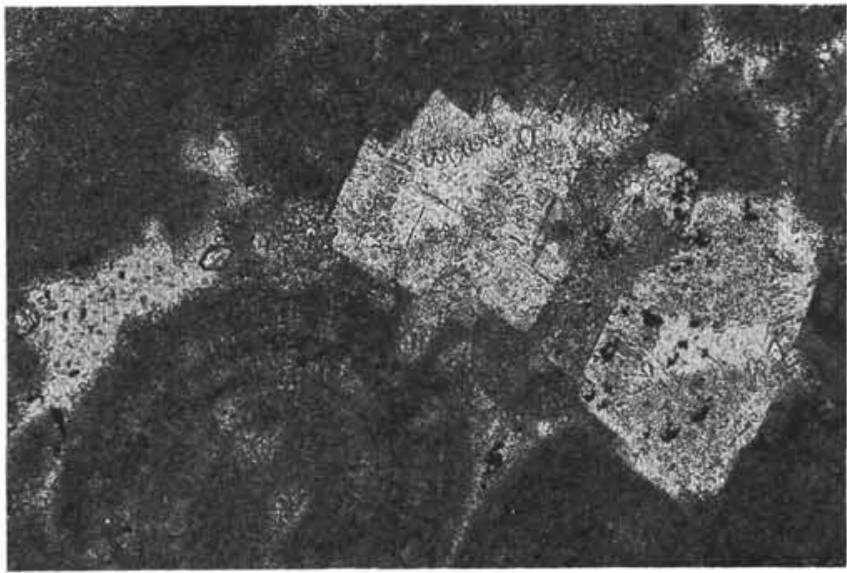

$0 . \overline{\mathrm{mm}}$

Figure 7. Grainstone with radial ooids and some void-filling and replacement dolomite. Dolomite rhombs have initially grown in pore space and then invaded ooids and peloids (Photomicrograph, plane light, Interval 143-866A-166R-1, $11-15 \mathrm{~cm}$; scale $0.1 \mathrm{~mm}$; Subunit VIIIA, Hauterivian).

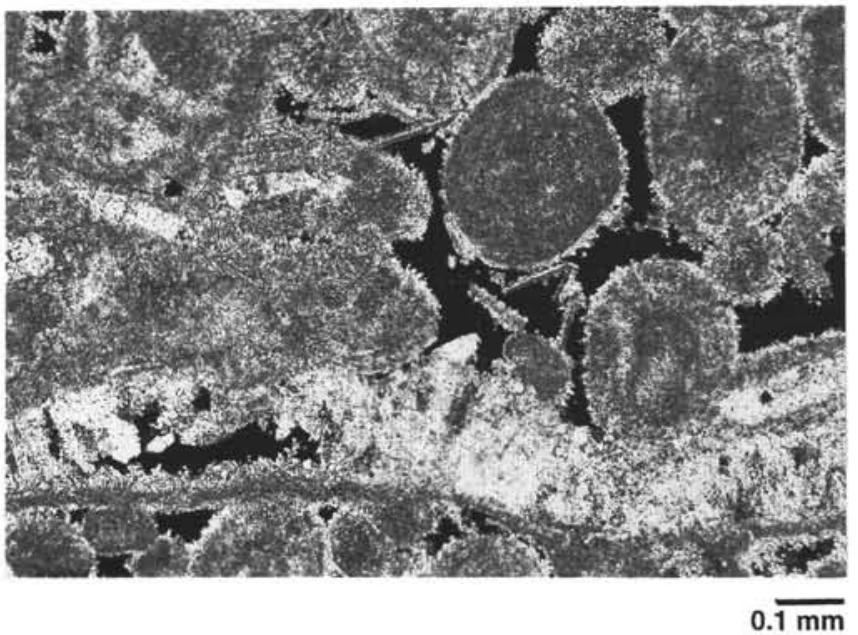

Figure 8. Oosparite showing overpacking (left) and spalling of outer cortical layers and cement fringes (Photomicrograph, polarized light, Sample 143866A-154R-1, 110-112 cm; scale $0.1 \mathrm{~mm}$; Subunit VIIIA, Hauterivian).

which induced precipitation of radially arranged carbonate crystals (Chafetz, 1986).

A typical feature in the oolitic facies is the epitaxial growth of radial ooid crystals into an early diagenetic fringing cement (Figs. 13, 14). Typically, these crystals grow larger toward the pore space. With their bladed shape and scalenohedral terminations (Fig. 15), they recall modern high-magnesian cements typical of shallow normal marine diagenetic environments and thus suggest an original composition of this kind. Microprobe analyses, however, consistently show $\mathrm{MgCO}_{3}$-concentrations below $2 \%$, which implies inversion to low-magnesian calcite without loss of crystal morphology. Equally, all the radial crystals of the ooid cortices are now composed of lowmagnesian calcite, but their epitaxial relationship with the fringing cement implies a high-magnesian calcite precursor. As shown by Gavish and Friedman (1969) and Budd and Hiatt (1993), high-Mg calcite inverts to low-Mg calcite without loss of textural integrity when exposed to meteoric-water diagenesis. This evidence supports the contention of Richter (1983) that ancient radial ooids from marine environments were composed originally of high-magnesian calcite. 


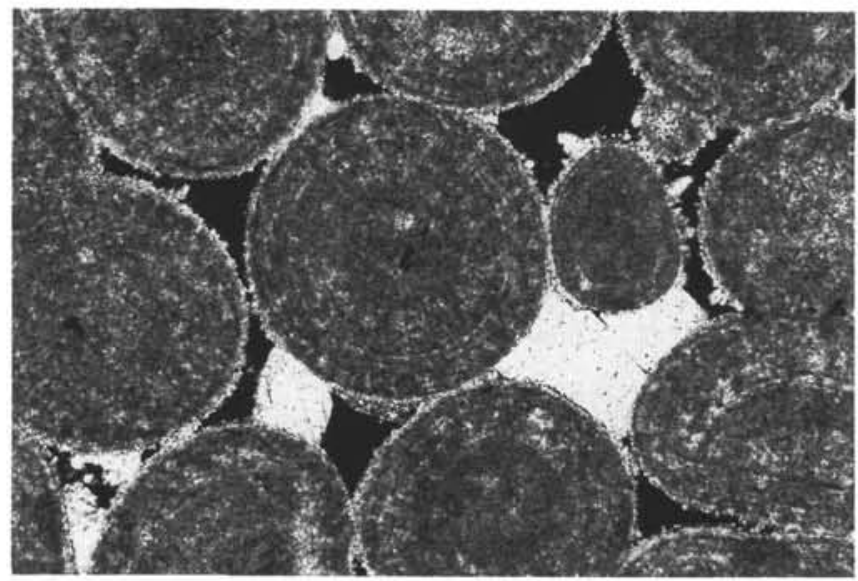

$0.1 \overline{\mathrm{mm}}$

Figure 9. Oolitic grainstone cemented by early fringing cement and later coarse calcite spar. Note that the presence of coarse crystals seems to prevent the compactional overpacking which is visible to the right and left of picture (Photomicrograph, polarized light, Sample 143-866A-169R-2, 113-114 cm; scale $0.1 \mathrm{~mm}$; Subunit VIIIB, Hauterivian).

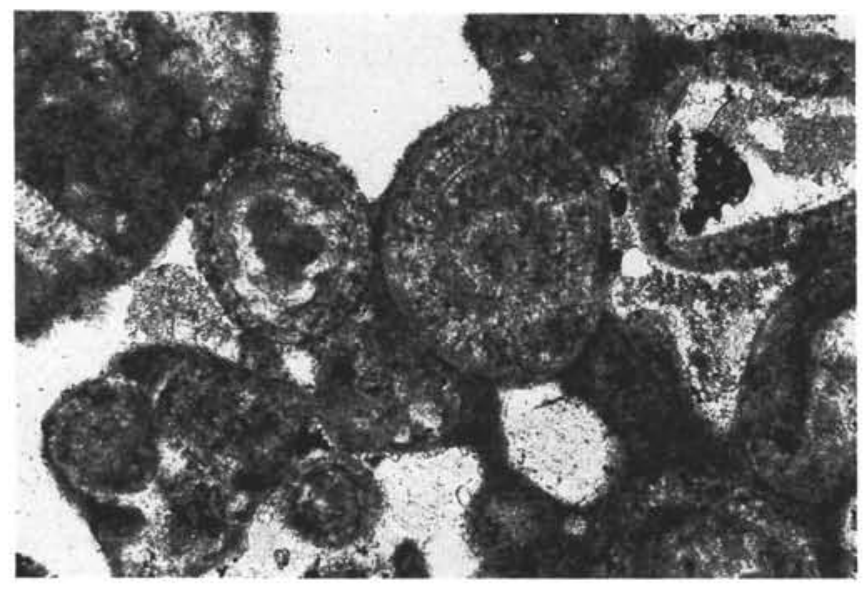

$0 . \overline{\mathrm{mm}}$

Figure 10. Radial ooids bound by micritic meniscus cement, suggesting a vadose early-diagenetic environment (Photomicrograph, plane light, Interval 143-866A-125R-3, 19-21 cm; scale $0.1 \mathrm{~mm}$; Subunit VIC, Barremian).

Tangential arrangement of cortical crystals has been observed only in particles of a mixed oncolitic-oolitic structure (Fig. 16). Such an arrangement probably formed through calcification of microbial coatings.

A noticeable feature of many ooids is their high degree of interpenetration, with local development of sutured contacts. Such pressure-solution phenomena must have provided a significant source of early diagenetic cement for the oolitic limestones. Local blocky cement crystals superposing the early fringing cement and growing into pore space (Fig. 14) have been interpreted as low-magnesium calcites precipitated in the meteoric/phreatic zone (Röhl and Strasser, this volume). Precipitation of this cement was probably concomitant with dissolution of molluscan and algal aragonitic material (e.g., Bathurst, 1975).

These ooids generally are similar to those that occur on Ita Matai Guyot in that the cortex "displays either distinctly concentric light and darker laminae or a diffuse dark brown micrite with a nebulous radial arrangement of the cortex material" (Hesse, 1973), but dissimilar in

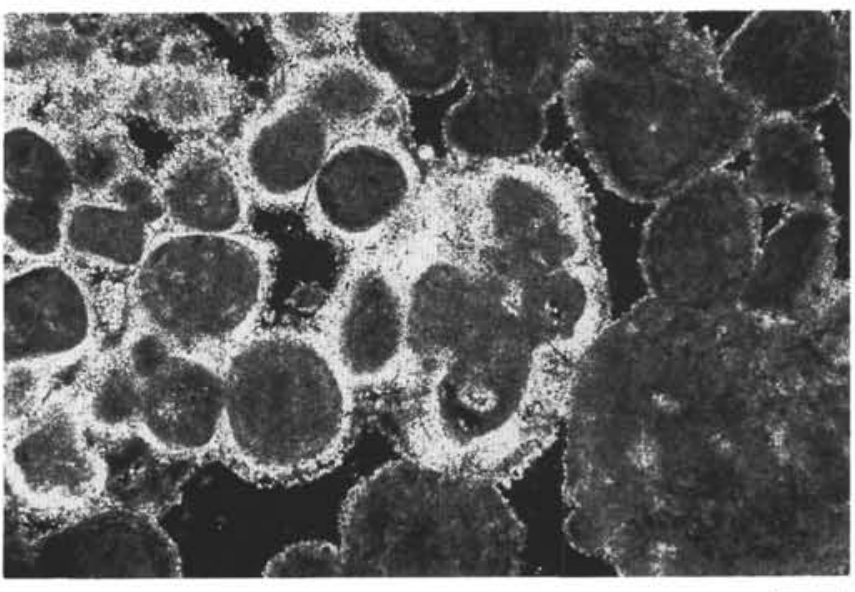

$0 . \overline{\mathrm{mm}}$

Figure 11. Oolitic grainstone-rudstone with piece of reworked hardground which is preferentially cemented by isopachous, fibrous cement. Note slight overpacking, which also affects cement (Photomicrograph, polarized light, Sample 143-866A-78R-3, 90-91 cm; scale $0.1 \mathrm{~mm}$; Unit V, Aptian).

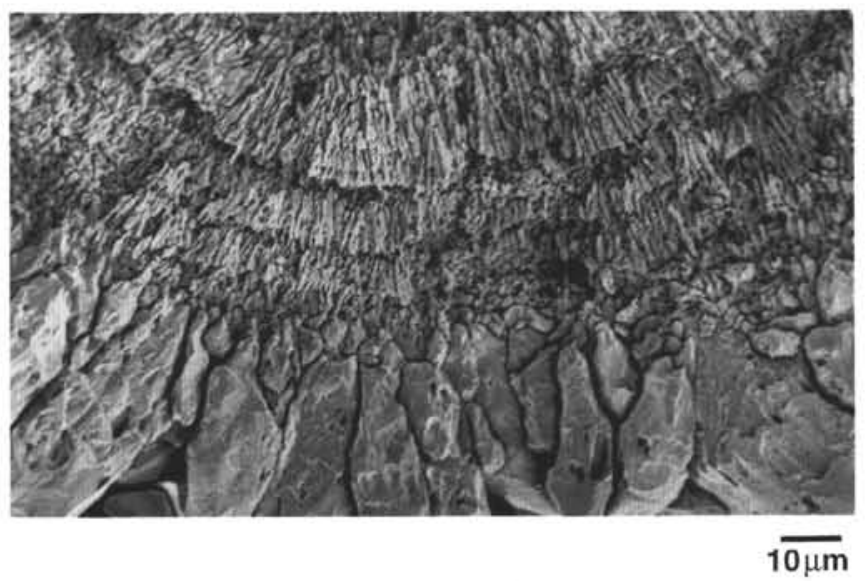

Figure 12. Well-developed radial cortical structure of ooid with concentric banding. Note local patches of micrite. Large crystals at bottom are fringing cement with epitaxial growth on ooid cortex, becoming larger toward center of pore (SEM photograph, Sample 143-866R-95R-1, 26-28 cm, Subunit VIB, Aptian).

that broken ooids do not constitute a common nucleus. The redeposited ooids from the east Mariana Basin appear petrographically identical to those from Resolution Guyot, with similar cortices and similar nuclei (Haggerty and Premoli Silva, 1986).

The processes that gave rise to Pacific Cretaceous ooids seem to lie somewhere along a spectrum that has fine particle adhesion at one end (to produce primary micritic bodies) and crystallization of radial calcite at the other. In the first case, these ooids can be considered as micro-oncolites that formed through the action of a cyanobacterial film (see Jenkyns, 1972), in the latter case, as some kind of inorganic or possibly organically modulated precipitate (Mitterer, 1968). Micritization of original ooid structure by boring micro-organisms has also been important (Bathurst, 1975). The interpretation of ancient radial ooids as primary precipitates now is commonplace (Sandberg, 1975; Simone, 1981; Richter, 1983) and compilations of inferred ooid mineralogy through time suggests that calcite, possibly magnesiumrich, was the favored precipitate during the Jurassic and Cretaceous (Sandberg, 1983; Wilkinson et al., 1985; Strasser, 1986). 


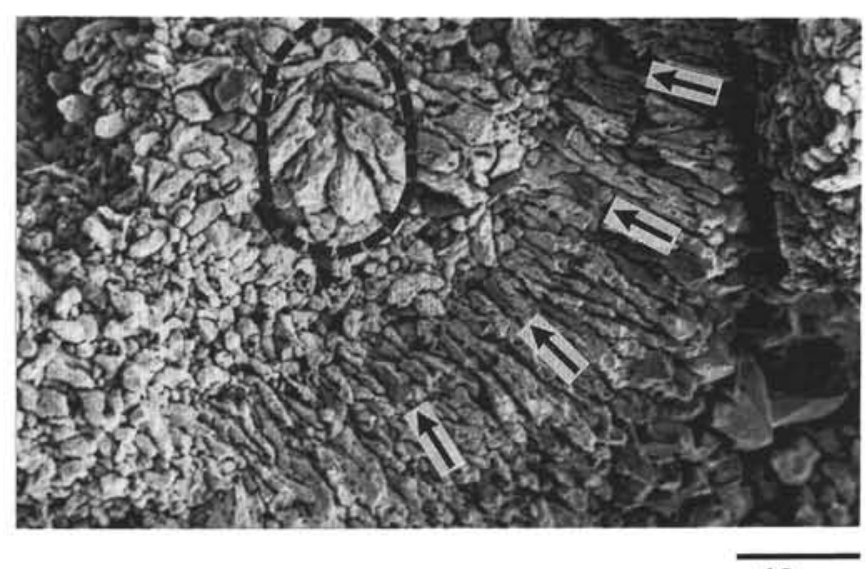

$10 \mu \mathrm{m}$

Figure 13. Spherulite (outlined) of probably microbial origin in micritic ooid core. Note well-developed epitaxial fringing cement with highly elongate crystals. Original ooid surface (arrow; SEM photograph, Sample 143-866A139R-1, 21-22 cm; Subunit VIIC, Barremian).

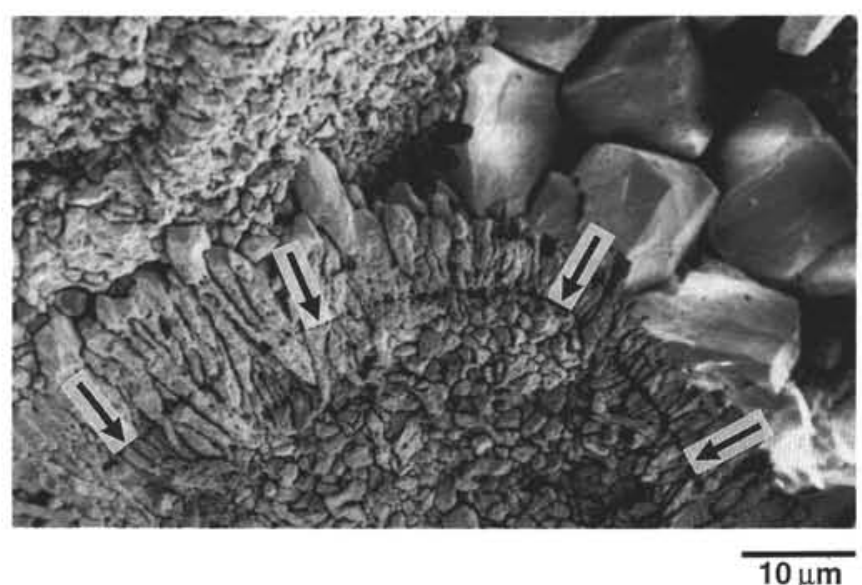

Figure 14. Epitaxial growth of originally (?) high-Mg calcite fringing cement on radial ooid cortex. Original ooid surface shown with arrow. Note that cement is less developed where ooid surface is micritic. Blocky calcite spar partly fills pore space (SEM photograph, Sample 143-866A-139R-1, 21-22 cm; Subunit VIIC, Barremian).

Inferred original calcitic as opposed to aragonitic mineralogy of ooids has been primarily related to two factors. The first of these is elevated $\mathrm{CO}_{2}$ levels in the ocean-atmosphere system (Mackenzie and Piggott, 1981), a phenomenon readily linked to the excessive volcanism of the mid-Cretaceous (Arthur et al., 1985; Larson, 1991). The second is a depressed $\mathrm{Mg} / \mathrm{Ca}$ ratio in seawater, which is related to increased seawater cycling through ocean ridges as spreading rates increased, and consequent magnesium loss. Because the volume of the ocean basins would decrease as rates of seafloor spreading increased and thermal rejuvenation of the lithosphere and excess volcanism became widespread, eustatic sea level would necessarily rise (Pitman, 1978; Schlanger et al., 1981). An association between rise in eustatic sea level and calcitic mineralogy of ooids would thus be predicted (Wilkinson et al., 1985; Sandberg, 1985).

\section{DEPOSITIONAL ENVIRONMENTS}

Summarizing for both the principal sequences of oolitic limestone, it is apparent that the facies associations and sedimentary struc-

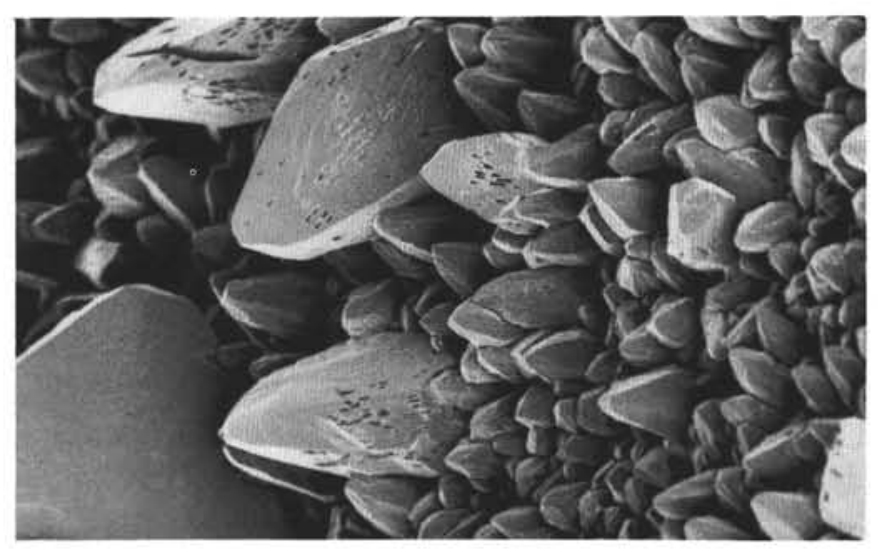

$10 \overline{\mu \mathrm{m}}$

Figure 15. Scalenohedral terminations of calcite crystals, interpreted as original high-Mg calcite (SEM photograph, Sample 143-866R-95R-1, 26-28 cm; Subunit VIB, Aptian).

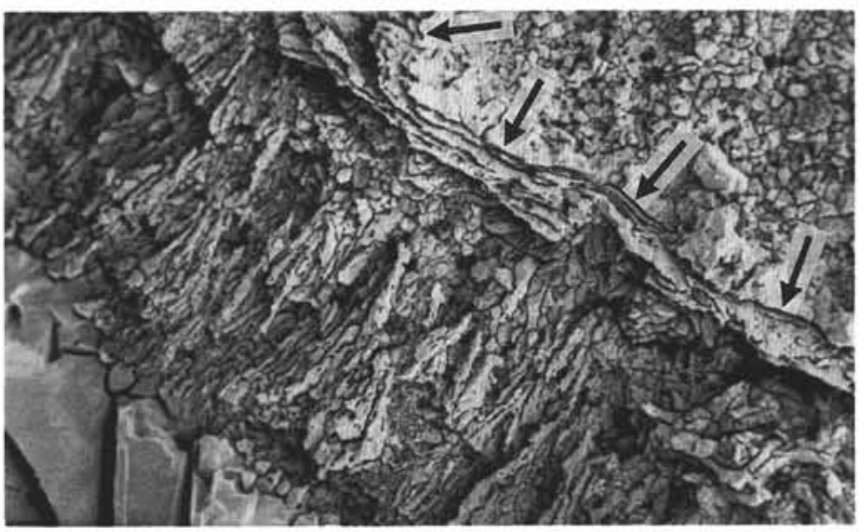

$1 \overline{0 \mu \mathrm{m}}$

Figure 16. Tangential coating of micritic core (arrow), probably representing calcified microbial layers. Radial oolitic cortex is superposed (SEM photograph, Sample 143-866A-167R-1, 63-65 cm; Subunit VIIIA, Hauterivian).

tures in both packages imply deposition in normal marine turbulentwater environments. The clean-washed nature of the original sediment and the hydrodynamic sorting of grains are diagnostic in this respect. Water depths were undoubtedly extremely shallow, and the oolite bars were emergent at times to form beaches, as indicated by the presence of keystone vugs (Dunham, 1970), or even supratidal ridges where meniscus cements, typical of the vadose zone, could precipitate (Dunham, 1971). In the Aptian oolitic package, a generally shallow depositional environment is also suggested by the association of the oolites with micrites of characteristic peritidal origin and local lacustrine facies.

Close comparisons can be made with the oolitic sand bars that have formed on the margins of the Bahama Banks (Ball, 1967; Bathurst, 1975; Hine, 1977; Hine et al., 1981; Harris, 1983). Drawing on these analogs, it seems probable that the oolite sand bodies formed and migrated principally under the influence of strong tidal currents close to a break in slope, in this case, the edge of Resolution Guyot; or conceivably under the influence of wind and wave agitation extending farther toward the interior (Wanless and Tedesco, 1993). The paucity of bioturbation implies that these mobile substrates were virtual submarine deserts, supporting perhaps only a few rapidly burrowing bivalves, as in the case of Bahamian oolite shoals (Purdy, 1964). Despite 
this sedimentary mobility, submarine lithification took place locally to produce hardgrounds, some of which were eroded to form clasts, just as described from the strongly agitated oolitic sands of the Bahamas (Dravis, 1979). Off-bank migration of the sand bodies took place from time to time, resulting in their transport into deep water, as shown by the presence of oolite-bearing turbidites adjacent to Resolution Guyot (Fig. 2). There is evidence for similar redeposition of ooids and peloids from off the Bahama Banks (Bornhold and Pilkey, 1971).

The formation of Bahamian oolitic sand bodies is clearly related to the Holocene rise in sea level (Hine, 1977; Harris, 1983), and this genetic link is relevant for understanding the development of Pacific Cretaceous oolitic deposits.

\section{OOLITES AND CHANGES IN RELATIVE SEA LEVEL}

The two intervals of abundant oolite generation can be related to changes in relative sea level or, more usefully, to an increase in accommodation space. This latter concept is defined by Jervey (1988) as "the space made available for potential sediment accumulation."

In the early stages following extrusion of the basaltic edifice that constitutes the igneous basement of Resolution Guyot, subsidence would have been relatively rapid. If the lower oolite section represents half of the Barremian stage and a small fraction of the Hauterivian, then the time elapsed during its deposition should lie between 4 and $5 \mathrm{Ma}$ (time scales of Harland et al., 1990; Obradovich, 1993), giving an average sedimentary rate of 80 to $110 \mathrm{~m} / \mathrm{m}$.y. Corresponding subsidence rates, which must have been similar to this, may have positioned the carbonate factory in a so-called "keep up" mode to maintain the sediment/water interface close to sea level in a hydrodynamic and physiographic environment conducive to ooid formation (see Kendall and Schlager, 1981). Essentially, such a situation would have tended to favor development of a wave-washed platform or ramp without the development of abundant lagoonal and peritidal facies, at least in the marginal region of the guyot cored at Site 866 (see Read, 1985). Development of grainstones is a typical response to such a physiography (Sarg, 1988), and oolites are characteristic of many platform margins, including those that have been semi-drowned, then recovered (Bosellini, 1989).

The gradual increase in fine-grained lime mudstone and concomitant decrease in ooid abundance upsection suggest a lessening of accommodation space with time, which allowed the carbonates to build up to sea level and to prograde, creating extended shallow lagoons and tidal flats. This could be explained simply by exponential decrease in the rate of basement subsidence with time as the seafloor followed its ordained subsidence track (Parsons and Sclater, 1977; Johnson and Carlson, 1992).

Clearly, however, a fundamental change took place with the deposition of the stratigraphically higher Aptian oolitic package, which overlies more finer-grained lithologies. The dating of this unit as late blowi to late algerianus zones of the Aptian is significant as this interval has been recognized in Europe as a time of significant regional transgression and deepening, punctuated by an intervening regression (Rawson and Riley, 1982; Haq et al., 1988; Hesselbo et al., 1990; Ruffell, 1991; Ruffell and Wach, 1991). Thus, it is tempting to view the increase in accommodation space represented by the oolites as a response to a eustatic signal (Fig. 3), and the package can be considered as part of a transgressive sequence formed by flooding of a carbonate bank. Average sedimentary rates for the Aptian stage, including the oolitic package, should lie in the range of 30 to 45 m/m.y., according to whether Harland et al.'s (1990) or Obradovich's (1993) time scale is adopted.

\section{IMPLICATIONS}

If the Aptian oolites reflect a genuine eustatic signal, then identical facies of identical age should be present across the Pacific, assuming a similar response of all guyot carbonates. The limited stratigraphic data available do not allow one to confirm this, but dating of isolated samples by strontium-isotope stratigraphy offers a route forward. The oolites from "MIT" Guyot and some of those from the Mariana Basin certainly are of Aptian age. A discrete level of Aptian oolitic grainstone is also recorded from the subsurface of Texas (Loucks and Bebout, 1984), but development of such sediments during this interval does not appear to have been characteristic of most Mediterranean carbonate platforms, even though more open-circulation rudistid facies are typically found (Masse, 1985; Sartorio, 1987). In fact, the Jurassic was the most oolitic period of the Mesozoic in the AlpineMediterranean region (D'Argenio, 1974; Bosellini, 1989). Exactly what conditions favored the generation of so much oolite across the Cretaceous Pacific Ocean remains enigmatic, although it must in part have related to the summit morphology of the volcanic edifices that characterized the Farallon and Pacific plates, as well as to changes in relative sea level.

\section{ACKNOWLEDGMENTS}

We are grateful to David Cummins for photographic work, Tony Watts for his help in preparing Figure 2, and Dehui Cao for preparing and photographing the SEM samples. A.S. acknowledges financial support from the Swiss National Science Foundation. Thoughtful and comprehensive reviews were furnished by Erik Flügel and Stephen Moshier.

\section{REFERENCES}

Arthur, M.A., Dean, W.E., Schlanger, S.O., 1985. Variations in the global carbon cycle during the Cretaceous related to climate, volcanism, and changes in atmospheric $\mathrm{CO}_{2}$. In Sundquist, E.T., and Broecker, W.S. (Eds.), The Carbon Cycle and Atmospheric $\mathrm{CO}_{2}:$ Natural Variations Archean to Present. Geophys. Monogr., Am. Geophys. Union, 32:504 529.

Bailey, E.H., Irwin, W.P., and Jones, D.L., 1964. Franciscan and related rocks, and their significance in the geology of western California. Bull.-Calif., Div. Mines Geol., 183.

Ball, M.M., 1967. Carbonate sand bodies of Florida and the Bahamas. J. Sediment. Petrol., 37:556-591.

Bathurst, R.G.C., 1975. Carbonate Sediments and Their Diagenesis (2nd ed.): Amsterdam (Elsevier).

Bornhold, B.D., and Pilkey, O.H., 1971. Bioclastic turbidite sedimentation in Columbus Basin, Bahamas. Geol. Soc. Am. Bull., 82:1341-1354.

Bosellini, A., 1989. Dynamics of Tethyan carbonate platforms. In Crevello, P.D., Wilson, J.J., Sarg, J.F., and Read, J.F. (Eds.), Controls on Carbonate Platform and Basin Development. Spec. Publ.-Soc. Econ. Paleontol. Mineral., 44:3-13.

Budd, D.A., and Hiatt, E.E., 1993. Mineralogical stabilization of high-magnesium calcite: geochemical evidence for intracrystal recrystallization within Holocene porcellaneous foraminifera. J. Sediment. Petrol., 63:261-274.

Chafetz, H.S., 1986. Marine peloids: a product of bacterially induced precipitation of calcite. J. Sediment. Petrol., 56:812-817.

D'Argenio, B., 1974. Le piattaforme carbonatiche periadriatiche. Una rassegna di problemi nel quadro geodinamico mesozoico dell'area mediterranea. In L'Italia nell'ambito dell'evoluzione del Mediterraneo. Mem. Soc. Geol. Ital., Suppl. 2, 13:137-160.

Dravis, J., 1979. Rapid and widespread generation of Recent oolitic hardgrounds on a high energy Bahamian Platform, Eleuthera Bank, Bahamas. J. Sediment. Petrol., 49:195-208.

Dunham, R.J., 1970. Keystone vugs in carbonate beach deposits. AAPG Bull., 54.

, 1971. Meniscus cement. In Bricker, O.P. (Ed.), Carbonate Cements. Johns Hopkins Univ. Stud. Geol., 19:297-300.

Ferry, S., and Schaaf, A., 1981. Early Cretaceous environment at Deep Sea Drilling Project Site 463 (Mid-Pacific Mountains), with reference to the Vocontian Trough (French Subalpine Ranges). In Thiede, J., Vallier, T.L.,

\footnotetext{
Abbreviations for names of organizations and publications in ODP reference lists follow the style given in Chemical Abstracts Service Source Index (published by American Chemical Society).
} 
et al., Init. Repts. DSDP, 62: Washington (U.S. Govt. Printing Office), $669-682$.

Gavish, E., and Friedman, G.M., 1969. Progressive diagenesis in Quaternary to late Tertiary carbonate sediments: sequence and time scales. J. Sediment. Petrol., 55:109-119.

Grötsch, J., and Flügel, E., 1992. Facies of sunken Early Cretaceous atoll reefs and their capping late Albian drowning succession (northwestern Pacific). Facies, 27:153-174.

Haggerty, J.A., and Premoli-Silva, I., 1986. Ooids and shallow-water debris in Aptian-Albian sediments from the East Mariana Basin, Deep Sea Drilling Project Site 585: implications for the environment of formation of the ooids. In Moberly, R., Schlanger, S.O., et al., Init. Repts. DSDP, 89: Washington (U.S. Govt. Printing Office), 399-412.

Haq, B.U., Hardenbol, J., and Vail, P.R., 1988. Mesozoic and Cenozoic chronostratigraphy and cycles of sea-level change. In Wilgus, C.K., Hastings, B.S., Kendall, C.G.St.C., Posamentier, H.W., Ross, C.A., and Van Wagoner, J.C. (Eds.), Sea-Level Changes-An Integrated Approach. Spec. Publ,-Soc. Econ. Paleontol. Mineral., 42:72-108.

Harland, W.B., Armstrong, R.L., Cox, A.V., Craig, L.E., Smith, A.G., and Smith, D.G., 1990. A Geologic Time Scale 1989: Cambridge (Cambridge Univ. Press).

Harland, W.B., Cox, A.V., Llewellyn, P.G., Pickton, C.A.G., Smith, A.G., and Walters, R., 1982. A Geologic Time Scale: Cambridge (Cambridge Univ. Press).

Harris, P.M., 1983. The Joulters Ooid Shoal, Great Bahama Bank. In Peryt, T.M. (Ed.), Coated Grains: Berlin (Springer-Verlag), 132-141.

Hesse, R., 1973. Diagenesis of a seamount oolite from the west Pacific, Leg 20, DSDP. In Heezen, B.C., and MacGregor, I.D., et al., Init. Repts. DSDP, 20: Washington (U.S. Govt. Printing Office), 363-387.

Hesselbo, S.P., Coe, A.L., and Jenkyns, H.C., 1990. Recognition and documentation of depositional sequences from outcrop: an example from the Aptian and Albian on the eastern margin of the Wessex Basin. J. Geol. Soc. London, 147:549-559.

Hine, A.C., 1977. Lily Bank, Bahamas: history of an active oolite shoal. $J$. Sediment. Petrol., 47:1554-1581.

Hine, A.C., Wilber, R.J., and Neumann, C., 1981. Carbonate sand bodies along contrasting shallow bank margins facing open seaways in northern Bahamas. AAPG Bull., 65:261-290.

Jenkyns, H.C., 1972. Pelagic "oolites" from the Tethyan Jurassic. J. Geol., $80: 21-33$.

Jervey, M.T., 1988. Quantitative geological modeling of siliciclastic rock sequences and their seismic expression. In Wilgus, C.K., Hastings, B.S., Ross, C.A., Posamentier, H., Van Wagoner, J., and Kendall, C.G.St.C. (Eds.), Sea-Level Changes: An Integrated Approach. Spec. Publ.-Soc. Econ. Paleontol. Mineral., 42:47-69.

Johnson, H.P., and Carlson, R.L., 1992. Variation of sea floor depth with age: a test of models based on drilling results. Geophys. Res. Lett., 19:19711974.

Kendall, C.G.St.C., and Schlager, W., 1981. Carbonates and relative changes in sea level. In Cita, M.B., and Ryan, W.B.F. (Eds.), Carbonate Platforms of the Passive-type Continental Margins, Present and Past. Mar. Geol., 44:181-212.

Larson, R.L., 1991. Geological consequences of superplumes. Geology, 19:963-966.

Loucks, R.G., and Bebout, D.G., 1984. Shelf-interior carbonate grainstone shoals: Lower Cretaceous Pearsall Formation, South Texas. In Harris, P.M. (Ed.), Carbonate Sands-a Core Workshop. SEPM Core Workshop $5,334-364$.

Mackenzie, F.T., and Pigott, J.D., 1981. Tectonic controls of Phanerozoic sedimentary rock cycling. J. Geol. Soc. London, 138:183-196.

Masse, J.-P., 1985. Paléobiogéographie des Rudistes du domaine péri-méditerranéen à l'Aptien inférieur. Bull. Soc. Geol. Fr. Ser. 8, 1:715-721.

Mitterer, R.M., 1968. Amino acid composition of organic matrix in calcareous oolites. Science, 82:843-852.

Obradovich, J.D., 1993. A Cretaceous time scale. In Caldwell, W.G.E., and Kauffman, E.G. (Eds.), Cretaceous Evolution of the Western Interior Basin of North America. Spec. Pap. Geol. Assoc. Can., 39:379-396.
Parsons, B., and Sclater, J.G., 1977. An analysis of the variation of ocean floor bathymetry and heat flow with age. J. Geophys. Res., 82:803-829.

Pitman, W.C., 1978. Relationship between eustacy and stratigraphic sequences of passive margins. Geol. Soc. Am. Bull., 89:1389-1403.

Premoli Silva, I., Haggerty, J., Rack, F., et al., 1993. Proc. ODP, Init. Repts., 144: College Station, TX (Ocean Drilling Program).

Purdy, E.G., 1964. Sediments as substrates. In Imbrie, J., and Newell, N.D., (Eds.), Approaches to Paleoecology: New York (Wiley).

Rawson, P.F., and Riley, L.A., 1982. Latest Jurassic-Early Cretaceous Events and the "Late Cimmerian Unconformity" in the North Sea area. AAPG Bull., 66:2628-2648.

Read, J.F., 1985. Carbonate platform facies models. AAPG Bull., 69:1-21.

Richter, D.K., 1983. Calcareous ooids: a synopsis. In Peryt, T.M. (Ed.), Coated Grains: Berlin (Springer-Verlag), 71-115.

Ruffell, A., 1991. Sea-level events during the Early Cretaceous in western Europe. Cretaceous Res., 12:527-551.

Ruffell, A., and Wach, G.D., 1991. Sequence stratigraphic analysis of the Aptian-Albian Lower Greensand in southern England. Mar. Pet. Geol., $8: 341-353$.

Sager, W.W., Winterer, E.L., Firth, J.V., et al., 1993. Proc. ODP, Init. Repts., 143: College Station, TX (Ocean Drilling Program).

Sandberg, P.A., 1975. New interpretations of Great Salt Lake ooids and ancient non-skeletal carbonate mineralogy. Sedimentology, 22:427-537. , 1983. An oscillating trend in Phanerozoic non-skeletal carbonate mineralogy. Nature, 305:19-22.

, 1985. Nonskeletal aragonite and $\mathrm{pCO}_{2}$ in the Phanerozoic and Proterozoic. In Sundquist, E.T., and Broecker, W.S. (Eds.), The Carbon Cycle and Atmospheric $\mathrm{CO}_{2}$ : Natural Variations Archean to Present. Am. Geophys. Union, Geophys. Monogr., 32:585-594.

Sarg, J.F., 1988. Carbonate sequence stratigraphy. In Wilgus, C.K., Hastings, B.S., Kendall, C.G.St.C., Posamentier, H., Ross, C.A., and Van Wagoner, J. (Eds.), Sea-Level Changes: An Integrated Approach. Spec. Publ.-Soc. Econ. Paleontol. Mineral., 42:155-181.

Sartorio, D., 1987. Reef and open episodes on a carbonate platform margin from Malm to Cenomanian: the Cansiglio example (Southern Alps). In Carulli, G.B., Cucchi, F., and Pirini Radrizzani, C. (Eds.), Evolution of the Karstic Carbonate Platform: Relation with Other Periadriatic Carbonate Platforms. Mem. Soc. Geol. Ital., 40:91-97.

Schlanger, S.O., 1987. Oolite facies as a transitional unit in deepening-upward carbonate sequences in atoll, seamount, and guyot settings in the Pacific Basin. AAPG Bull., 71:610-611.

Schlanger, S.O., Jenkyns, H.C., and Premoli-Silva, I., 1981. Volcanism and vertical tectonics in the Pacific Basin related to global Cretaceous transgressions. Earth Planet. Sci. Lett., 52:435-449.

Simone, L., 1981. Ooids: a review. Earth Sci. Rev, 16:319-355,

Strasser, A., 1986. Ooids in Purbeck limestones (lowermost Cretaceous) of the Swiss and French Jura. Sedimentology, 33:711-727.

Tarduno, J.A., McWilliams, M., Debiche, M.G., Sliter, W.V., and Blake, M.C., Jr., 1985. Franciscan Complex Calera limestones: accreted remnants of Farallon Plate plateaus. Nature, 317:345-347.

Thiede, J., Vallier, T.L., et al., 1981. Init. Repts. DSDP, 62: Washington (U.S. Govt. Printing Office)

Wachs, D., and Hein, J.R., 1974. Petrography and diagenesis of Franciscan limestones. J. Sediment. Petrol., 44:1217-1231.

Wanless, H.R., and Tedesco, L.P., 1993. Comparison of oolitic sand bodies generated by tidal vs. wind-wave agitation. In Keith, B.D., and Zuppann, C.W. (Eds.), Mississippian Oolites and Modern Analogs. AAPG, Stud. Geol., 35:199-225.

Wilkinson, B.H., Owen, R.M., and Carroll, A.R., 1984. Submarine hydrothermal weathering, global eustasy, and carbonate polymorphism in Phanerozoic marine oolites. J. Sediment. Petrol., 55:171-183.

Date of initial receipt: 5 October 1993

Date of acceptance: 6 April 1994

Ms 143SR-211 